\title{
HOW A RIDGE-FURROW RAINWATER HARVESTING SYSTEM WITH PLASTIC FILM-MULCHED RIDGES AFFECTS RUNOFF GENERATION, RAINFALL STORAGE, AND WATER MOVEMENT IN SEMI-ARID REGIONS IN CHINA
}

\author{
Qu Yang ${ }^{1,2}$, Gao Xiaoli ${ }^{1}$, Feng Baili ${ }^{1 *}$ \\ ${ }^{1}$ College of Agronomy, Northwest A\&F University, Yangling, Shaanxi, China \\ ${ }^{2}$ Baoji Institute of Agricultural Science, Qishan, Shaanxi, China \\ *E-mail: 7012766@163.com
}

\begin{abstract}
Ridge-furrow rainwater harvesting with alternate white plastic film-mulching has been shown to be an easy and efficient method to harvest rainwater and improve crop yield in arid and semi-arid regions in China. To explore how this system affects the pattern of water movement, the water content of the soil, and runoff generation, two systems were designed and tested in Fugu, Yulin, Shaanxi, China from 2010 to 2012. There were three treatment groups as follows: a flat control plot with no mulching (NM), a plot with furrow and ridge widths of $60 \mathrm{~cm}$ (P60), and a plot with furrow and W-shaped ridge widths of $40 \mathrm{~cm}$ (W80). W80 was found to have a higher mean rate of runoff generation than $\mathrm{P} 60$ (83.1\% and $70.3 \%$, respectively). Additionally, compared with the other groups, W80 exhibited increased rainwater storage beneath the furrow in both rainy and dry seasons. The water content of the soil beneath the ridges of all treatment groups was higher after rainfall than before rainfall, and the rainwater infiltration rate was higher at $24 \mathrm{~h}$ after rainfall than at $48 \mathrm{~h}$ after rainfall. Moreover, the water content of the soil under the ridge was higher at the pre-measured stage than at the later measured stage, suggesting that it is not effective for short-term rainfall. Yield, water use efficiency, and soil water storage of rainwater harvesting practices had more advantage than that of NM. These findings suggest that using a ridge-furrow rainwater harvesting system with alternate plastic film-mulching can improve runoff generation, increase rainwater storage, and decrease water loss from the soil. In this system, the water from the soil moved from planted furrows to ridges during rainfall, but the water moved from ridges to planted furrows in the dry season. The W80 system with the $\mathrm{W}$-shaped ridge performed better than the other groups with respect to rainwater storage, evaporation control, runoff generation, and water use efficiency.
\end{abstract}

\section{KEY WORDS}

Furrow-ridge tillage, water storage, water movement, China.

In arid and semi-arid regions, rainfall is an important resource for rain-fed farming production (Cook et al., 2000). In this region, soil moisture is generally limited and crop growth is stressed by drought during the growing seasons, which often leads to unstable crops yield. This presents a serious environment problem for sustainable agricultural development (Wu et al., 2000). To cope with the water shortage problem, it is necessary to adopt water-saving agriculture countermeasures to achieve the largest possible increase in water use efficiency of crops (Wang et al., 2001; Shao et al., 2007). How to use limited rainfall is a key 
countermeasure for solving crop water need shortage and increasing crop yield under no irrigation condition ( $\mathrm{Li}$ and Gong, 2002). In this situation, rainwater harvesting practices is introduced to use rainfall effectively and meet crop water need in arid and semi-arid areas (Evenari et al., 1968).

A key effect of this practice is effective utilization of light rain. And concentration of surface runoff in light rain has been practiced for thousands of years around the world (Bruins et al., 1986). Micro-catchment water harvesting (MCWH) and the ridge and furrow rainfall harvesting (RFPH) can improve soil moisture storage and enhance growth of agricultural crops (Liakatas et al., 1986; Muller, 1991; Gupta, 1995). Further, the furrow/ ridge with plastic-film mulch originated from ridge/ furrow rainfall harvesting system, which is more effective in reducing evaporation, increasing soil temperature, maintaining soil water, and increasing crop yield (Li et al., 2001; Ramakrishna et al., 2006; Luis Ibarra-Jimenez et al., 2011). On a commercial scale, rainwater harvesting practices can be applied easily because of low investment cost (Tian et al., 2003; Wang et al., 2009), it has been used for many years in different crops, such as maize (Zhang et al., 2011), wheat (Song et al., 2002), potato (Wang et al., 2003), and proso millet (Qu et al., 2012) act so on in arid and semi-arid regions. However, precipitation and soil water storage may constrain to utilize of furrow/ ridge practices, and increasing yield would depend on the amount of precipitation during the crop growth season (Wang et al., 2009). Pacey and Culliis (1986) pointed out that the rainfall of $100 \mathrm{~mm}$ was the lowest annual rainfall suitable for rainwater concentration and rainfall of 200 $\mathrm{mm}$ was more favorable for this purpose. Ben-Asher et al (1987) suggested the system of micro-catchments water harvesting would be suitable for desert regions with about $250 \mathrm{~mm}$ annual rainfall. Ren et al (2008) showed that rainwater harvesting practices doesn't necessary adapt to all rainfalls, and the optimal annual rainfall to adopt this system is likely below 440 $\mathrm{mm}$ during the whole period of corn growth. In previous researches, it was found that rainfall extremely limitation, increasing yield, and increasing water use efficiency could be emphasized. In their research, how furrow/ ridge with plastic-film mulched supplies with rainfall and how soil water moves between planting furrow and plastic-film mulched ridge in rainy and dry season was still not shown. Therefore, the present experiment, which explores soil water movement between planting furrow and ridge with plastic-film mulched in stage of crop growth, is an effort to fill that knowledge gap.

The objective of this study was to explore rainwater harvesting practices with respect to supplemental pattern of soil water and its impact on runoff generation, rainwater storage, crop yield and water use in semi-arid regions of the Loess plateau.

\section{MATERIALS AND METHODS OF RESEARCH}

Study site. Rainfall harvesting systems with furrows and plastic film-mulched ridges were conducted at Canghemao Experimental Station, Northwest A \& F university, Fugu, Shaanxi province $\left(39.09^{\circ} \mathrm{N}, 111.01^{\circ} \mathrm{E}\right.$ and altitude $\left.1000 \mathrm{~m}\right)$ during three growing seasons of proso millet in 2010-2012. The study location is semi-arid regions with annual mean precipitation of $366.2 \mathrm{~mm}$; a mean annual temperature is $9.1{ }^{\circ} \mathrm{C}$ with a maximum of $38.9{ }^{\circ} \mathrm{C}$ and the minimum of $-24{ }^{\circ} \mathrm{C}$; an average annual pan evaporation of $1092.2 \mathrm{~mm}$; an average annual sunshine duration of $2890 \mathrm{~h}$ and a frost-free period of over 177 frost-free days. Soil 
type is calciccambisols whose properties at each depth were showed in table 1 . Analysis of the top soil $(0-20 \mathrm{~cm})$ obtained the following results: organic $C$ content of $19.32 \mathrm{~g} \mathrm{~kg}^{-1}$, a nitrate $\mathrm{N}$ content of $1.2 \mathrm{~g} \mathrm{~kg}^{-1}$; an available $\mathrm{P}$ content of $6.4 \mathrm{mg} \mathrm{kg}^{-1}$, an available $\mathrm{K}$ content of $89 \mathrm{mg} \mathrm{kg}^{-1}$, an ammonium $\mathrm{N}\left(\mathrm{NH}_{4}{ }^{+}+\mathrm{NO}_{3}{ }^{-}\right)$content of $44.3 \mathrm{mg} \mathrm{kg}^{-1}$, and soil bulk density of $1.50 \mathrm{~g} \mathrm{~cm}^{-3}$.

Table 1 - Measurements stage of soil water

\begin{tabular}{lllllll}
\hline \multirow{2}{*}{ Year } & \multicolumn{2}{l}{ Effective rainfall } & & \multicolumn{2}{l}{ No effective rainfall } \\
\cline { 2 - 7 } & $\begin{array}{l}\text { Before rainfall } \\
\text { (month-day) }\end{array}$ & $\begin{array}{l}\text { After rainfall } \\
\text { (month-day) }\end{array}$ & $\begin{array}{l}\text { Actual rainfall time } \\
\text { (month-day) }\end{array}$ & $\begin{array}{l}\text { Precipitation } \\
(\mathrm{mm})\end{array}$ & $\begin{array}{l}\text { Sampled stage } \\
\text { (month-day) }\end{array}$ & $\begin{array}{l}\text { Duration } \\
\text { (d) }\end{array}$ \\
\hline 2010 & $7-23$ & $7-25,7-26,7-27$ & $7-24$ & 10.5 & $7-25 / 8-4$ & 10 \\
2011 & $7-27$ & $7-30,7-31,8-1$ & $7-28,7-29$ & 18.5 & $7-4 / 7-16$ & 13 \\
2012 & $7-29$ & $7-31,8-1,8-2$ & $7-30$ & 23.0 & $7-14 / 7-29$ & 16 \\
\hline
\end{tabular}

Experimental design. Rainfall harvesting systems, be often used in arid and semi-arid regions, were designed as follows: the width of furrow was $60 \mathrm{~cm}$ with $60 \mathrm{~cm}$ wide ridge (P60) (Fig. 1), the width of furrow was $40 \mathrm{~cm}$ with $40 \mathrm{~cm}$ wide W-shaped ridge (W80) (Fig. 2), and a flat plot with no mulching (NM) is as a control. P60 and W80 with plot areas of $4.8 \times 5 \mathrm{~m}^{2}$ and $3.2 \times 5 \mathrm{~m}^{2}$ were composed of four ridges and furrows alternately. Plot of NM had an area of $3.2 \times 5 \mathrm{~m}^{2}$. All systems and control plot had three replications that were arranged in a randomized block design, and buffer row between treatments was 1 row. Ridges of P60 and W80 were covered with $0.008 \mathrm{~mm}$ plastic film (Height: $10 \mathrm{~cm}$ ), and both ends of plastic film were perpendicular to furrow surface and embedded in soil (Depth: $5 \mathrm{~cm}$ ). The entire experimental area was ploughed after all fertilizers $\left(34.5 \mathrm{~N} \mathrm{~kg} \mathrm{ha}^{-1}, 9.0 \mathrm{P}_{2} \mathrm{O}_{5} \mathrm{~kg} \mathrm{ha}^{-1}\right.$ ) were incorporated into the soil surface (Plough depth: $20 \mathrm{~cm}$ ), and fertilizing amount was controlled by conventional method. The cultivar "Yumi 2 " of proso millet with density of $5.0 \times 10^{5}$ plants ha $^{-1}$ were sown on 11 June and harvested on 25 September in 2010, sown on 12 June and harvested on 23 September in 2011 and sown on 15 June and harvested on 27 September in 2012, respectively.

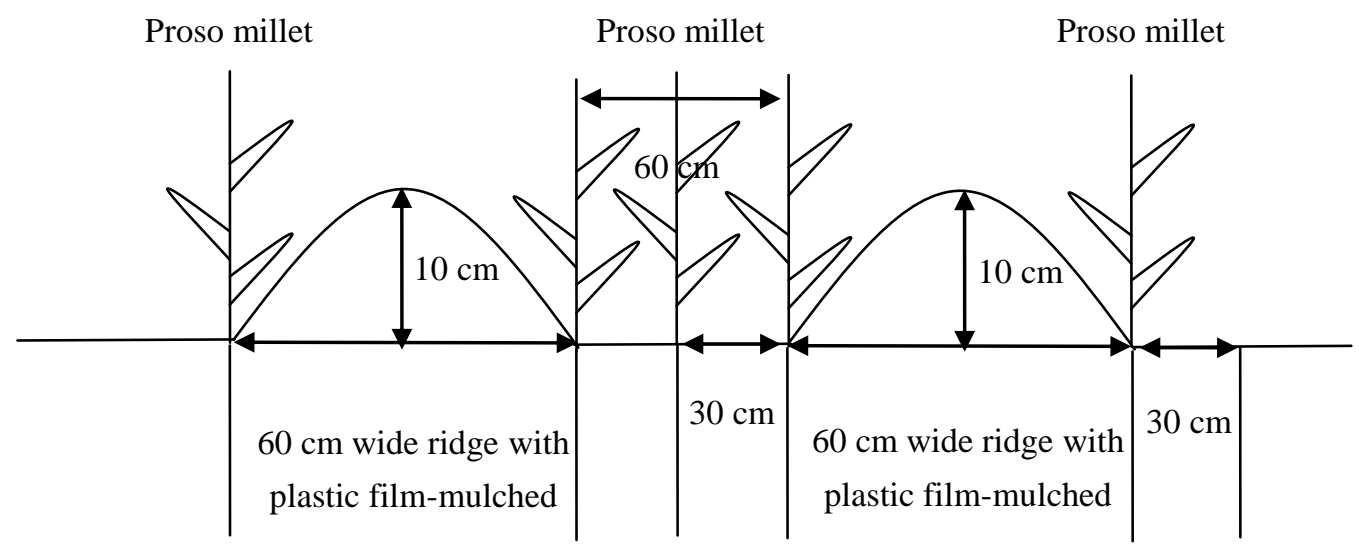

Figure 1 - P60, the rainwater harvesting practice with $60 \mathrm{~cm}$ wide ridges with plastic film-mulched 


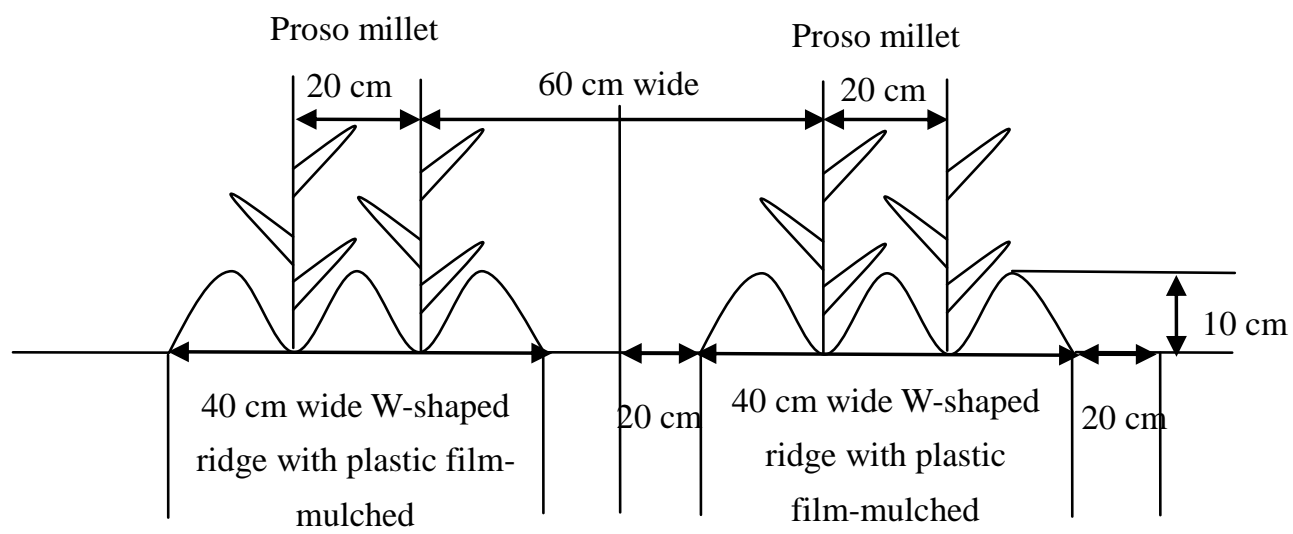

Figure 2 - W80, the rainwater harvesting practice with $40 \mathrm{~cm}$ wide $\mathrm{W}$-shaped ridges with plastic film-mulched

Sampling and measurements. Measurements were made before rainfall, after rainfall and no effective rainfall in the short term, respectively during growing season of proso millet (Table 2).

Table 2 - Properties of the different soil layers at the experimental site

\begin{tabular}{lllll}
\hline $\begin{array}{l}\text { Soil layer depth } \\
(\mathrm{cm})\end{array}$ & $\begin{array}{l}\text { Soil bulk density } \\
\left(\mathrm{g} \cdot \mathrm{cm}^{-3}\right)\end{array}$ & Soil porosity & $\begin{array}{l}\text { Wilting coefficient } \\
\left(\mathrm{g} \cdot \mathrm{kg}^{-1}\right)\end{array}$ & $\begin{array}{l}\text { Field capacity } \\
\left(\mathrm{g} \cdot \mathrm{kg}^{-1}\right)\end{array}$ \\
\hline $0-20$ & 1.50 & 0.43 & 25 & 48 \\
$20-40$ & 1.64 & 0.38 & 30 & 57 \\
$40-60$ & 1.63 & 0.39 & 27 & 51 \\
$60-80$ & 1.62 & 0.39 & 26 & 49 \\
$80-100$ & 1.52 & 0.43 & 22 & 41 \\
\hline
\end{tabular}

The water content of soil in $0-100 \mathrm{~cm}$ soil profile was determined at depth intervals of 20 $\mathrm{cm}$. Measurements were made approximately every two weeks during the growing seasons of proso millet. Soil samples in three positions of each treatment (planting furrow or ridge) randomly were collected and kept separately in aluminium box. The soil samples were obtained and oven-dried at $105^{\circ} \mathrm{C}$ for $24 \mathrm{~h}$. Soil water storage capacity was calculated by formula (Ren et al., 2008):

$$
W=h \times p \times b \% \times 10
$$

In which, W stands for soil water storage capacity, h stands for soil depth, $\mathrm{p}$ stands for soil bulk weight, and b\% stands for percentage of soil water in weight. Soil water storage in the profile was considered to be the total storage $(0-100 \mathrm{~cm})$.

The runoff generation rate $\left(R G_{R}\right)$, the increasing water storage rate $\left(I W S_{R}\right)$, and the water infiltration rate $\left(\mathrm{WI}_{\mathrm{R}}\right)$ were determined using the formulas (Han et al., 2004):

$$
\begin{gathered}
R G_{R}(\%)=\left(\Delta W_{T}-\Delta W_{N M}\right) / R \times 100 \% \\
I W S_{R}(\%)=\left(\Delta W_{T}-\Delta W_{N M}\right) / \Delta W_{N M} \times 100 \% \\
W I_{R}(\%)=\left(W h_{p}-W h_{l}\right) /\left(h_{p}-h_{l}\right) \times 100 \%
\end{gathered}
$$


Both $\Delta W_{T}$ and $\Delta W_{N M}$ are increasing soil water content of treatment and $N M$ after rainfall, $\mathrm{mm}$; $R$ is precipitation $(\mathrm{mm})$ between previous measurement and later measurement. $W h_{p}$ is soil water storage of previous measured, which was measured before rainfall; $W h_{l}$ is soil water storage of later measured, which was measured after rainfall. WUE can be indicated as follows by the kernel yield per unit ET (Li et al., 2001; Wang et al., 2005).

$$
\begin{gathered}
\text { RHFRS: } E T=P+E_{r} \frac{n_{1}}{n_{2}} p+\left(W_{1}-W_{2}\right) \\
W U E=\frac{Y}{E T \times \frac{n_{2}}{n_{1}+n_{2}}}
\end{gathered}
$$

Flat: $E T=\left(W_{1}-W_{2}\right)+P$

$$
W U E=\frac{Y}{E T}
$$

In the formula, $E T$ is evaporation ( $\mathrm{mm})$; WUE is water use efficiency $(\mathrm{kg} \cdot \mathrm{mm}-1 \cdot \mathrm{hm}-2)$; $W_{1}$ and $W_{2}$ represent soil water content before sowing and after maturity at $100 \mathrm{~cm}$ soil layer $(\mathrm{mm})$ (the soil water content of furrow/ridge plant area was the average water capacity in furrows, beside ridges and in the middle of ridges); $E r$ is the runoff efficiency of plastic film-mulched ridges (\%) (the mean runoff efficiency is 0.87 ) (Li et al., 2001); $P$ is rainfall during growth stage $(\mathrm{mm}) ; n_{1}$ and $n_{2}$ denote the ridge width and furrow width $(\mathrm{cm})$, respectively; yield $(Y$ ) in furrow and ridge system refers to the grain yield according to calculating by furrow/ridge total area, and then we can get water use efficiency of grain yield.

All data were analyzed by SAS v6 and Microsoft Excel 2007 software, and mean values were compared by Duncan' method $(P<0.05)$.

\section{RESULTS OF STUDY}

Runoff generation. Table 3 shows the runoff generation rate of rainfall harvesting systems during 2010-2012 seasons. For water content of soil, two rainfall harvesting systems had higher values than those of NM $(P<0.05)$ before rainfall and after rainfall. Water content of soil after rainfall had advantage enough compared with that before rainfall.

Table 3 - Runoff generation rate of rainfall harvesting practices

\begin{tabular}{llllll}
\hline Year & Planting area & Before rainfall $(\mathrm{mm})$ & After rainfall $(\mathrm{mm})$ & Rainfall $(\mathrm{mm})$ & $R G_{R}(\%)$ \\
\hline \multirow{2}{2}{2010} & P60 & b $408.0 \pm 21.4$ & b $446.2 \pm 21.3$ & 10.5 & b $70.5 \pm 3.4$ \\
& W80 & a $417.2 \pm 23.9$ & a $457.0 \pm 22.9$ & & a $85.7 \pm 4.8$ \\
& NM & c $360.2 \pm 17.0$ & c $391.0 \pm 18.6$ & & - \\
\hline \multirow{2}{*}{2011} & P60 & b $394.4 \pm 20.7$ & b $443.0 \pm 22.2$ & 18.5 & b $70.8 \pm 3.6$ \\
& W80 & a $409.7 \pm 20.5$ & a $460.6 \pm 24.0$ & & a $83.2 \pm 4.4$ \\
& NM & c $385.2 \pm 18.3$ & c $420.7 \pm 21.0$ & & - \\
& P60 & b $568.4 \pm 28.4$ & b $627.7 \pm 33.4$ & 23.0 & b $69.6 \pm 3.3$ \\
& W80 & a $571.5 \pm 30.6$ & a $633.3 \pm 32.7$ & & a $80.4 \pm 4.1$ \\
\hline
\end{tabular}

Note: Mean value \pm Standard Deviation. Different letters within each year and parameter indicate significant differences $(P<0.05)$. 
As far as runoff generation rate was concerned, values of W80 were similar every year, values of $\mathrm{P} 60$ were either; However, W80 with a mean value of $83.1 \%$ had higher values than P60 with a mean value of $70.3 \%(P<0.05)$ during $2010-2012$ seasons.

Rainfall storage. Increasing water content of soil is calculated though water content of soil before rainfall and after rainfall. For increasing water content of soil, rainfall harvesting systems had higher value than those of NM $(P<0.05)$ during 2010-2012 seasons; values of P60 and W80 increased by $24.0 \%$ and $29.2 \%$ in 2010 , by $36.9 \%$ and $43.4 \%$ in 2011 , and by $37.0 \%$ and $42.7 \%$ in 2012, respectively compared with these of NM; W80 with a mean value of $38.4 \%$ had advantage enough compared with $\mathrm{P} 60$ with a mean value of $32.6 \%(P<0.05)$ in three growing seasons.

Decreasing water content of soil was measured during no effective rainfall of short term. Fig 4 shows decreasing water content of soil at previous measured stage and later measured stage. As far as decreasing water content of soil was concerned, rainfall harvesting systems could decrease soil evaporation (Fig 4) and had lower values than that of NM $(P<0.05)$ during 2010-2012 seasons; values of P60 and W80 decreased by $-21.3 \%$ and $-44.2 \%$ in 2010 , by $-12.7 \%$ and $-21.0 \%$ in 2011 , and by $-19.3 \%$ and $-25.0 \%$ in 2012 , respectively compared with these of NM; W80 with a mean value of $-30.1 \%$ had advantage enough compared with P60 with a mean value of $-17.8 \%(P<0.05)$ in three growing seasons.

Water movement between ridge and furrow. Table 4 reports results of water content of soil under the ridge of rainfall harvesting systems. As far as water content of soil under the ridge was concerned, W80 had higher values than those of $\mathrm{P} 60(P<0.05)$ before rainfall, after rainfall, after $24 \mathrm{~h}$ of measurement after rainfall and after $48 \mathrm{~h}$ of measurement after rainfall, respectively during 2010-2012 seasons. For increasing water content of soil under the ridge (Fig 5), W80 had advantage enough compared with that of $\mathrm{P} 60(P<0.05)$ in three growing seasons; later measurements, such as after $24 \mathrm{~h}$ and $48 \mathrm{~h}$ of previous measurement after rainfall, had lower values than that of previous measurement $(P<0.05)$ after rainfall in three growing seasons; last measurement, such as after $48 \mathrm{~h}$ of previous measurement after rainfall, had lower values than that of after $24 \mathrm{~h}$ of previous measurement after rainfall $(P<0.05)$ in three growing seasons; W80 with mean values of $44.8 \mathrm{~mm}, 11.4 \mathrm{~mm}$ and $4.5 \mathrm{~mm}$, respectively at previous measurement after rainfall, after $24 \mathrm{~h}$ of previous measurement after rainfall and after $48 \mathrm{~h}$ of previous measurement after rainfall, respectively had advantage enough compared with P60 with mean values of $37.0 \mathrm{~mm}, 7.9 \mathrm{~mm}$ and $4.5 \mathrm{~mm}$, respectively at that of the same as previous in three growing seasons.

Table 4 - Water content of soil under the ridge of rainfall harvesting systems

\begin{tabular}{|c|c|c|c|c|c|}
\hline Year & Ridge & Before rainfall $(\mathrm{mm})$ & After rainfall(mm) & After $24 \mathrm{~h}(\mathrm{~mm})$ & After $48 \mathrm{~h}(\mathrm{~mm})$ \\
\hline \multirow[t]{2}{*}{2010} & P60 & b $396.8 \pm 20.8$ & b $420.8 \pm 20.0$ & b $428.7 \pm 20.4$ & b $433.0 \pm 22.7$ \\
\hline & W80 & a $410.3 \pm 21.5$ & a $442.3 \pm 23.1$ & a $455.9 \pm 23.8$ & a $461.7 \pm 24.1$ \\
\hline \multirow[t]{2}{*}{2011} & P60 & b $363.2 \pm 19.2$ & b $408.5 \pm 21.4$ & b $416.1 \pm 21.8$ & b $419.8 \pm 22.0$ \\
\hline & W80 & a $384.7 \pm 18.2$ & a $435.7 \pm 21.8$ & a $445.7 \pm 21.3$ & a $450.2 \pm 22.5$ \\
\hline \multirow[t]{2}{*}{2012} & P60 & b $546.5 \pm 29.3$ & b $588.6 \pm 30.4$ & b $596.9 \pm 30.8$ & b $599.3 \pm 30.0$ \\
\hline & W80 & a $556.1 \pm 27.8$ & a $607.4 \pm 31.4$ & a $618.0 \pm 30.9$ & a $621.1 \pm 30.1$ \\
\hline
\end{tabular}

Note: Mean value \pm Standard Deviation. Different letters within each year and parameter indicate significant differences $(P<0.05)$. 


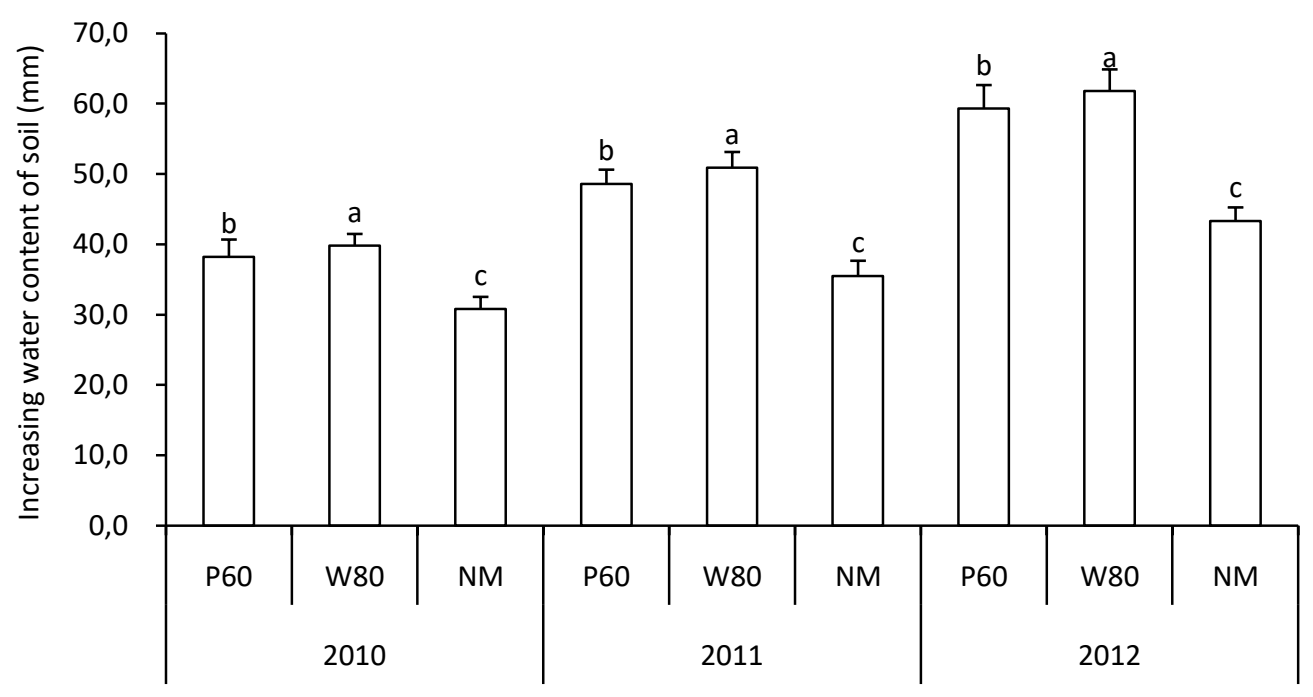

Figure 3 - Increasing water content of soil before rainfall and after rainfall

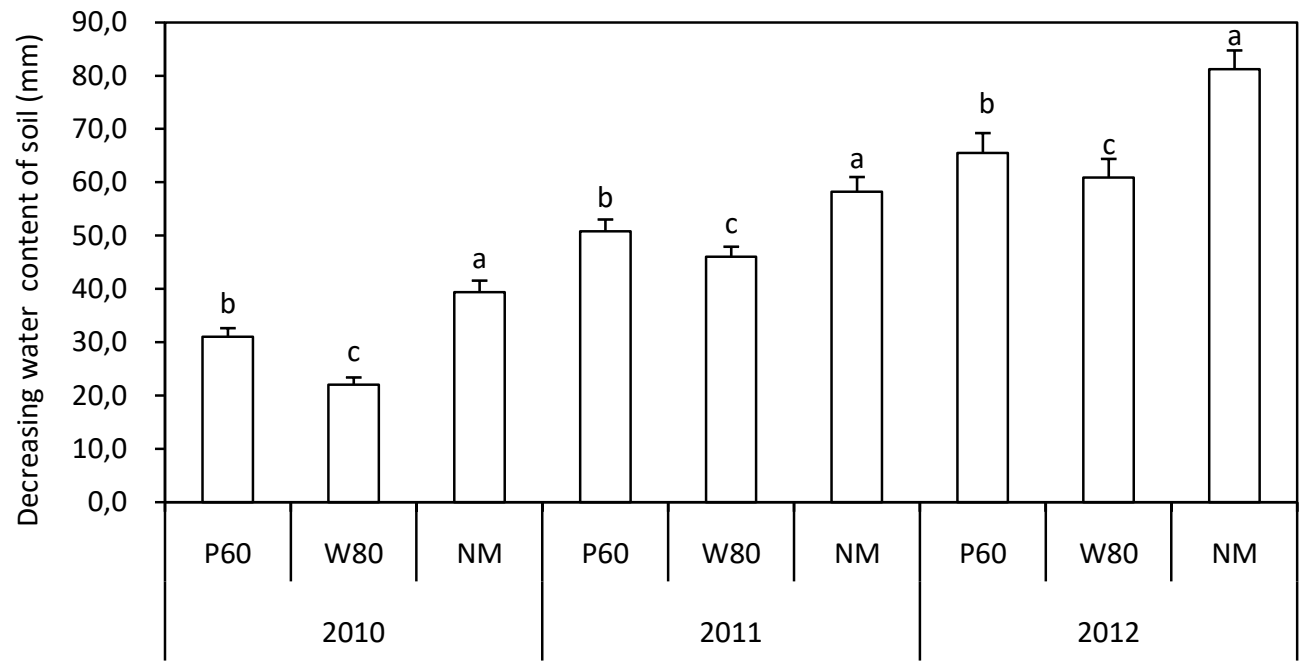

Figure 4 - Decreasing water content of soil during no effective rainfall of short term

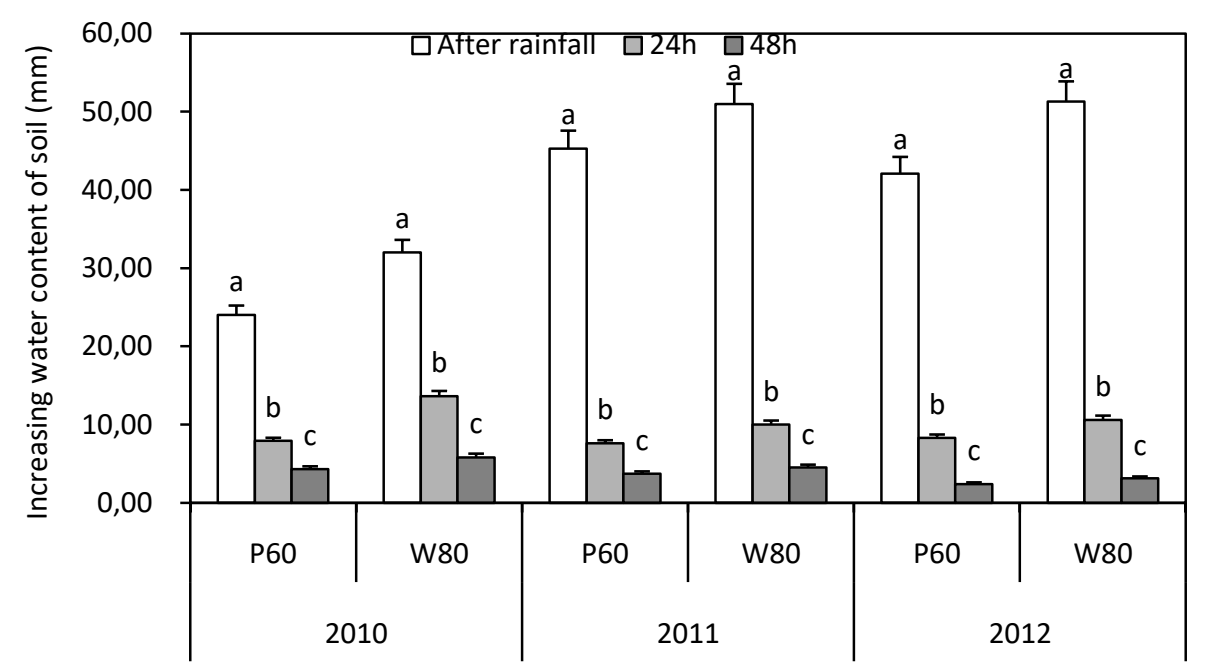

Figure 5 - Increasing water content of soil under the ridge before rainfall and after rainfall 


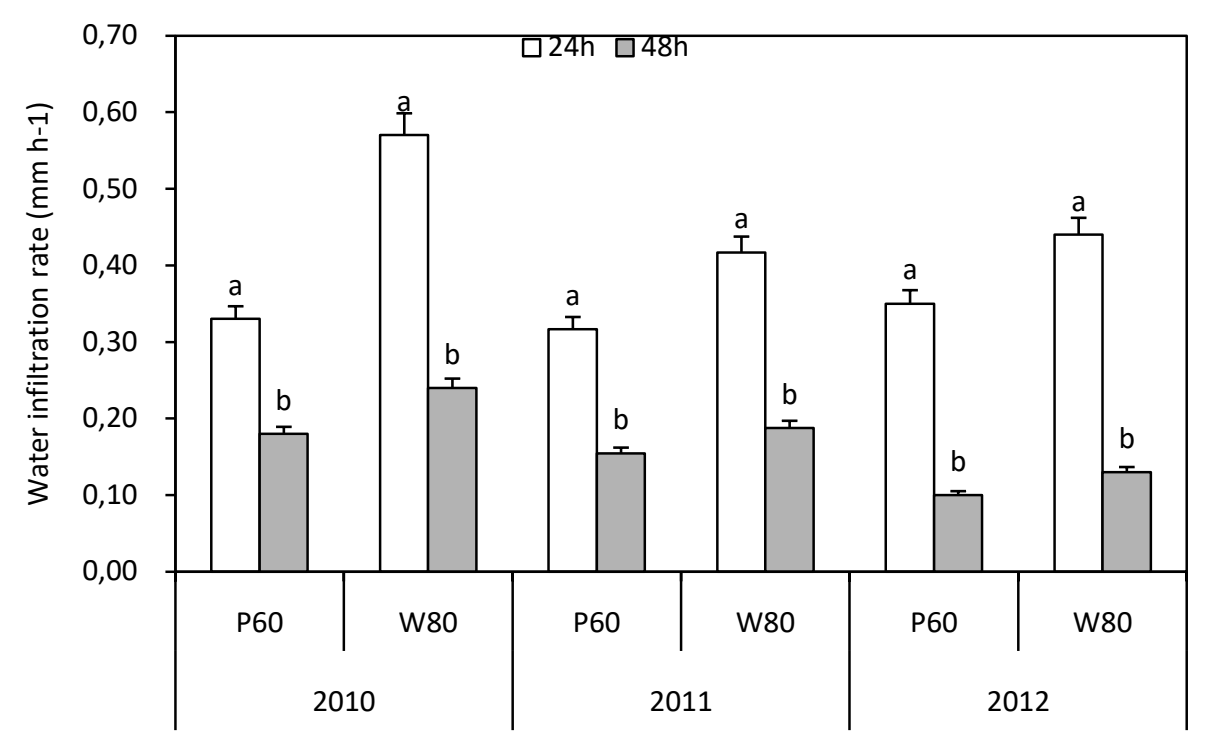

Figure 6 - Water infiltration rate between furrow and ridge

Water infiltration rate of soil is concerned with Fig 6. As time was longer water infiltration rate of soil was lower, and water infiltration rate of soil had significant difference $(P<0.05)$ within rainfall harvesting systems. As far as water infiltration rate of soil was concerned, W80 with mean values of $0.48 \mathrm{~mm} \mathrm{~h}^{-1}$ and $0.19 \mathrm{~mm} \mathrm{~h}^{-1}$ after $24 \mathrm{~h}$ of previous measurement after rainfall and after $48 \mathrm{~h}$ of previous measurement after rainfall had advantage enough compared with $\mathrm{P} 60$ with mean values of $0.33 \mathrm{~mm} \mathrm{~h}^{-1}$ and $0.14 \mathrm{~mm} \mathrm{~h}^{-1}$ at that of the same as previous in three growing seasons.

Fig 7 shows variation of water content of soil under the ridge. For variation of water content of soil of no effective rainfall in short term, water content of soil decreased between previous measured stage and later measured stage; water content of soil at previous measured stage had higher values than that of later measured stage $(P<0.05)$ in three growing seasons. As far as decreasing water content of soil was concerned, W80 with a mean value of $29.2 \mathrm{~mm}$ had advantage enough compared with $\mathrm{P} 60$ with a mean value of $33.9 \mathrm{~mm}$ in three growing seasons.

Soil water storage and water use efficiency. The water content of topsoil with different systems is presented in Table 5. At measured stage, topsoil water contents of different practices were higher than those of NM. At jointing stage, topsoil water content $(0-20 \mathrm{~cm})$ increased by $16.2 \%$ at P60 and $40.4 \%$ at W80 compared to those of NM. At mature stage, topsoil water content $(0-20 \mathrm{~cm})$ increased by $15.4 \%$ at P60 and $34.9 \%$ at W80 compared to those of NM. In 20-40 cm soil layer, rainwater harvesting practices increased topsoil water content of jointing stage by $17.5 \%$ at P60 and $44.3 \%$ at W80 and increased topsoil water contents of mature stage by $14.7 \%$ at P60 and $45.1 \%$ at W80. And compared to control plots in measured topsoil layer, soil water content at jointing stage increased by $19.6 \%$ at P60 and $43 \%$ at W80, and soil water content at mature stage increased by $15.2 \%$ at P60 and $41.8 \%$ at W80. On the whole, rainwater harvesting practices increased soil water at the growth stage of proso millet. 


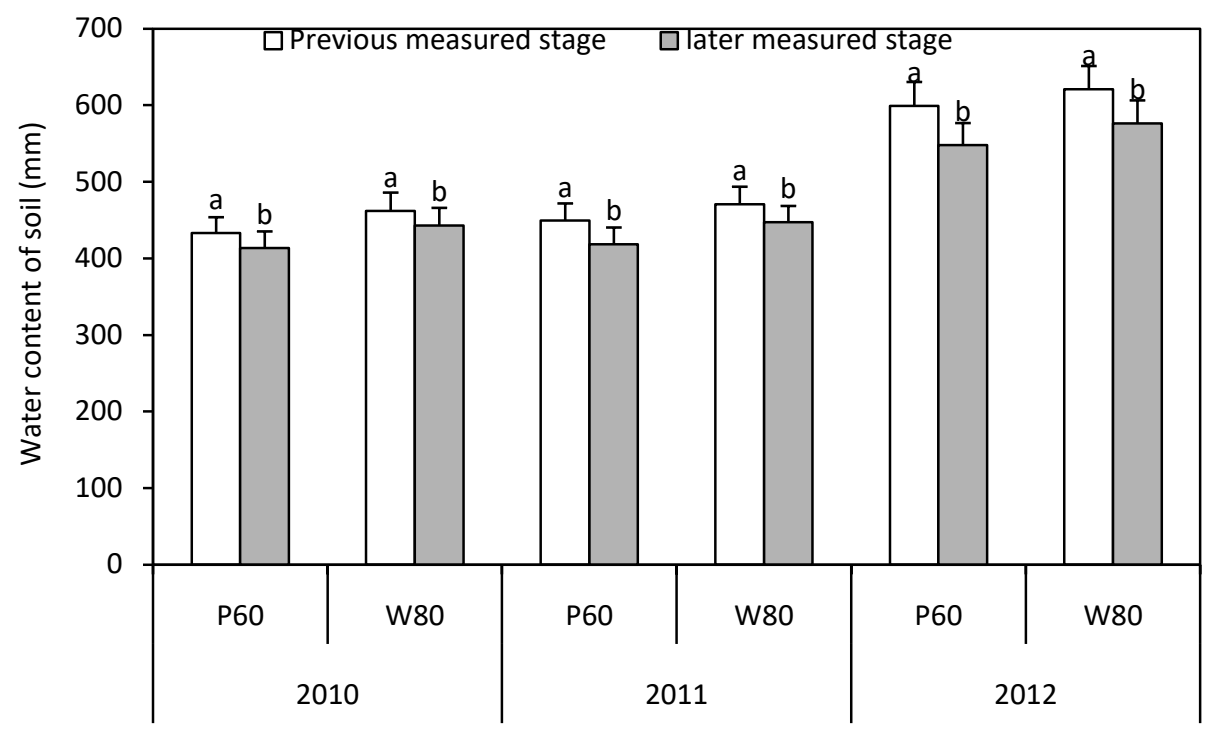

Figure 7 - Water content of soil under the ridge in no effective rainfall of short term

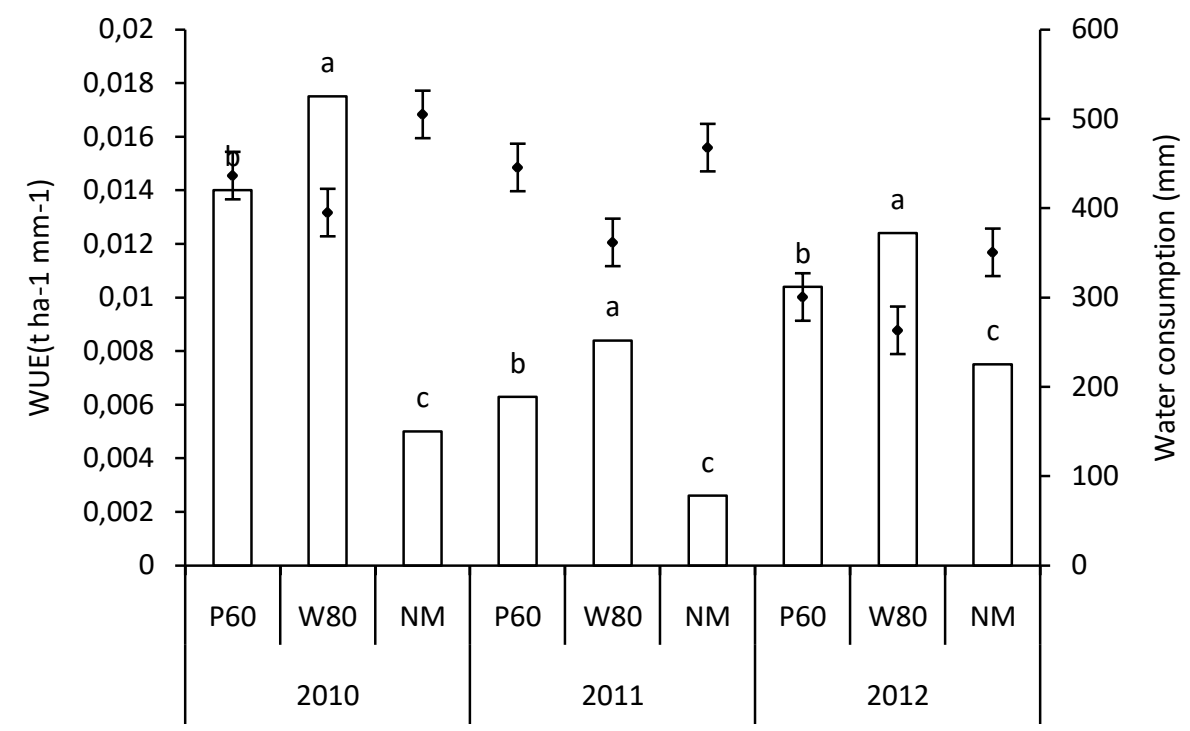

Figure 8 - Water use efficiency and water consumption in 2010-2012

Table 5 - Water contents of topsoil at the jointing and mature stages in 2010-2012. (mm)

\begin{tabular}{llllllll}
\hline \multirow{2}{*}{ Year } & Soil layer & \multicolumn{2}{l}{ Jointing stage } & \multicolumn{5}{l}{ Mature stage } \\
& $(\mathrm{cm})$ & NM & P60 & W80 & NM & P60 & W80 \\
\hline \multirow{2}{*}{2010} & $0-20$ & $14.7 \pm 0.7$ & $16.5 \pm 0.8$ & $20.7 \pm 1.2$ & $14.1 \pm 1.0$ & $17.5 \pm 1.0$ & $26.0 \pm 0.9$ \\
& $20-40$ & $30.6 \pm 1.2$ & $34.6 \pm 1.0$ & $42.0 \pm 2.1$ & $22.8 \pm 1.1$ & $33.0 \pm 2.0$ & $42.8 \pm 2.7$ \\
\multirow{4}{*}{2011} & $0-20$ & $18.7 \pm 0.9$ & $20.1 \pm 1.0$ & $23.0 \pm 1.2$ & $10.7 \pm 0.7$ & $12.0 \pm 0.6$ & $18.6 \pm 1.2$ \\
& $20-40$ & $41.9 \pm 2.1$ & $46.3 \pm 3.2$ & $57.5 \pm 2.9$ & $24.7 \pm 1.1$ & $25.1 \pm 1.6$ & $30.6 \pm 1.8$ \\
\multirow{3}{*}{2012} & $0-20$ & $37.0 \pm 1.9$ & $45.4 \pm 2.3$ & $55.1 \pm 2.1$ & $27.6 \pm 1.6$ & $31.0 \pm 1.8$ & $26.1 \pm 1.7$ \\
& $20-40$ & $90.8 \pm 3.6$ & $116.8 \pm 4.7$ & $135.9 \pm 5.2$ & $50.2 \pm 3.3$ & $54.3 \pm 4.5$ & $68.7 \pm 2.4$ \\
Mean & $0-20$ & 23.5 & 27.3 & 33 & 17.5 & 20.2 & 23.6 \\
& $20-40$ & 54.4 & 65.9 & 78.5 & 32.6 & 37.4 & 47.3 \\
& $0-40$ & 77.9 & 93.2 & 111.4 & 50 & 57.6 & 70.9 \\
\hline
\end{tabular}


WUE and soil water consumption of rainwater harvesting practices had more significant effects than those of NM $(P<0.05)$ (Fig 8). W80 recorded the lowest soil water consumption (395, 361.1 and $263.2 \mathrm{~mm}$ in 2010, 2011 and 2012). Soil water consumption of rainwater harvesting practices decreased by 64.4-112.3 mm compared to NM. And difference between two rainwater harvesting practices were significant $(P<0.05)$.

Opposite to soil water consumption, the highest WUE was recorded in W80 $(0.0175$, 0.0084 and $0.0124 \mathrm{t} \mathrm{ha}^{-1} \mathrm{~mm}^{-1}$ in 2010, 2011 and 2012). WUE in rainwater harvesting practices increased by $52-215 \%$ compared to control plots. And difference between two rainwater harvesting practices were significant $(P<0.05)$.

Thus, all data showed that rainwater harvesting practices greatly decreased soil water consumption and had a large effect on water use efficiency.

\section{DISCUSSION OF RESULTS}

Rainfall runoff. Runoff is an important factor for water loss, still harvesting runoff in planting furrow is a key problem for crop production in rain-fed agricultural regions. Conservation tillage, as a technique of influencing rainfall runoff, has been reported on runoff rates. Several studies have shown no-till resulted in greater runoff than conventional till systems (Logan et al., 1994; Afyuni et al., 1997; Smith et al., 2007). However, several studies have shown conservation tillage reduced runoff volumes (Truman et al., 2009; Krutz et al., 2009). Rainwater harvesting practices with furrows and plastic film-mulched ridges were reported to harvest and retain surface runoff (Xie et al., 2005; Jia et al., 2006).

Observing rainfall runoff generation of this study, runoff generation rates of two practices were clear each year and similar in different growing seasons, which showed runoff generation rates of two rainwater harvesting practices were stable and to maintain to be high effective. Related findings were different from unstable results in conservation tillage, which indicated that rainwater harvesting practices performed well for runoff generation. This positive effect may be attributed to slope plastic-film (Zhang et al., 2007), and furrow/ ridge design and plastic-film may influence runoff generation rate. In present research, it was "W-shaped" practice that had advantage enough in runoff generation.

Soil water movement. Water movement of furrows and plastic film-mulched ridge was considered according to findings of Han Q F et al. (2004). Soil water moves from sowing furrow to ridge with plastic-film mulched when $W_{h p}$ is higher than $W_{h l}$, or else soil water moves from ridge with plastic-film mulched to sowing furrow.

As far as rainfall event were concerned, soil water content under plastic-film mulched ridge before rainfall event was lower than that after rainfall event $\left(\mathrm{W}_{\mathrm{hp}}<\mathrm{W}_{\mathrm{hl}}\right)$, which showed water movement was from sowing furrow to ridge with plastic film-mulched. Water infiltration rate was lower when time is longer, which showed water infiltration rate decreased little by little when rainfall supply was not enough. In no rainfall of short term ( $>10$ days), soil water content under plastic-film mulched ridge at previous measured stage was higher than that later measured stage $\left(\mathrm{W}_{\mathrm{hp}}>\mathrm{W}_{\mathrm{hl}}\right)$, which indicated water movement was from plastic film-mulched ridge to sowing furrows.

It was water movement of rainwater harvesting practices with furrows and plastic film-mulched ridges that had two important results, a) at rainy stage, soil water movement was 
from sowing furrow to ridge with plastic film-mulched; b) at dry stage, soil water movement was from plastic film-mulched ridges to sowing furrow. These results suggested that it was the relationship of soil water movement between furrow and plastic-film mulched ridges.

Rainfall storage and WUE. In semi-arid and arid regions, water storage is an important factor for crop growth ( $\mathrm{Li}$ and Xiao, 1992). How to harvesting rainfall and rainfall storage is a key point for crop production in rain-fed farming. Observing values of rainfall storage, rainwater harvesting practices had advantage enough compared to those of NM. At rainfall stage or dry stage, rainwater harvesting practices had better effect on increasing soil water content and maintaining soil water content at different growth stage compared to those of NM. Moreover, rainwater harvesting practices decreased soil water consumption and lastly obtained high yield and water use efficiency. These findings are consistent with those of other studies (Anikwe et al., 2007; Liu et al., 2010). However, we found that different rainwater harvesting practices had different effects on augmented available soil water. Especially, special shape of ridge had a large effects on increasing and maintaining soil water content under the ridge, which may put down to harvest more precipitation due to large superficial area with plastic-film mulched (Botha et al.,2015; Yang et al., 2015;); in this study, "W-shaped" system was found and had advantage enough in rainfall storage.

\section{CONCLUSION}

Rainwater harvesting practices could improve runoff, increase soil water content, decrease soil water consumption, and enhance water use efficiency. Topsoil water of rainwater harvesting practices was from planted furrow to ridges with white plastic film-mulched in rainy, while topsoil water was from ridge with white plastic to planted furrow in drought season. "W-shaped" practices had full advantage in present research.

\section{ACKNOWLEDGEMENTS}

This work was supported by National Natural Science Foundation of China (31371529), and National Millet Crops Research and Development System (Project No. CARS-07-12.5-A9).

\section{REFERENCES}

1. Afyuni, M.M., Wagger, M.G., Leidy, R.B., 1997. Runoff of two sulfonylurea herbicides in relation to tillage system and rainfall intensity. Journal of Environment Quality. 26, 1318-1326.

2. Anikwe, M.A.N., Mbah, C.N., Ezeaku, P.I., Onyia, V.N., 2007. Tillage and plastic mulch effects on soil properties and growth and yield of cocoyam (Colocasia esculenta) on an ultisol in southeastern Nigeria. Soil Tillage Res. 93, 264-272.

3. Ben-Asher J, Warrick A W. 1987.Effect of variations in soil properties and precipitation on microcatchment water balance. Agricultural Water Management, 12(3): 177-194.

4. Botha, J.J., Anderson, J.J., Van Stagen, P.P. 2015.Rainwater harvesting and conservation tillage increase maize yields in south Africa.Water Resources and Rural 
Development, 6,66-77.

5. Bruins, H.J., Evenari, M., Nessler, U., 1986. Rainwater-harvesting agriculture for food production in arid zones: the challenge of the African famine. Appl. Geography, 6,13-32.

6. Cook, S., Li, F., Wei, H., 2000. Rainwater harvesting agriculture in Gansu province. People's Republic of China. J. Soil Water Conserv. 55 (2), 112-114.

7. Evenari M, Shanan L, Tadmor N H. 1968. Runoff farming in the desert. I. Experimental layout. Agronomy Journal, 60(1): 29-38.

8. Gupta, G.N., 1995. Rainwater management for tree planting in the Indian desert. J.Arid Environ. 31,219-235.

9. Han Q F., li X T., Wang J P., Jiang J., Ding R X., Liu Z H., Jia Z K., 2004. Simulated study on soil moisture of field under water micro-collecting farming conditions. Transactions of the CSAE. 20 (2): 78-82. (in Chinese with English abstract)

10. Jia, Y., Li, F.M., Wang, X.L., Yang, H.M., 2006. Soil water and alfalfa yields as affected by alternating ridges and furrows in rainfall harvest in a semiarid environment. Field Crop Res. 97, 167-175.

11. Krutz, L.J., Locke, M.A., Stenriede Jr., R.W., 2009. Interactions of tillage and cover crop on water, sediment, and pre-emergence herbicide loss in glyphosate-resistant cotton: implications for the control of glyphosate-resistant weed biotypes. Journal of Environment Quality. 38, 1240-1247.

12. Li X Y, Gong J D. 2002.Effect of different ridge, furrow ratios and supplemental irrigation on crop production in ridge and furrow rainfall harvesting system with mulches. Agricultural Water Management, 54: 243-254.

13. Li X Y., Gong J D., Gao Q Z., Li F R., 2001. Incorporation of ridge and furrow method of rainfall harvesting with mulching for crop production under semiarid conditions. Agricultural Water Management. 50(3), 173-183.

14. Li, S., Xiao, L., 1992. Distribution and management of drylands in the People's Republic of China. Adv. Soil Sci. 18, 148-293.

15. Liakatas A., Clark J A., Monteith, J L., 1986. Measurements of the heat balance under plastic mulches Part I. Radiation balance and soil heat flux. Agricultural and Forest Meteorology. 36, 227-239.

16. Liu, Y., Yang, S., Li, S., Chen, X., Chen, F., 2010. Growth and development of maize (Zea mays L.) in response to different field water management practices: resource capture and use efficiency. Agr. Forest Meteorol. 150, 606-613.

17. Logan, T.J., Eckert, D.J., Beak, D.G., 1994. Tillage, crop and climatic effects on runoff and tile drainage losses of nitrate and four herbicides. Soil and Tillage Research. 30, 75-103.

18. Luis I-J R., Hugo L-S., Luis A V-A., Javier L-D R., 2011. Colored plastic mulches affect soil temperature and tuber production of potato. Acta Agriculturae Scandinavica, Section B Plant Soil Science. 61 (2), 1651-1913.

19. Muller A.,1991. Comportamento termico do solo e do ar em alface. (Lactuca sativa L.) para diferentes tipos de cobertura do solo. Piracicaba. Msc Thesis, Scola Superiorde Agricultura, universidade de sao Paulo. Pp, 77

20. Pacey A, Cullis A. 1986. Rainwater Harvesting: the Collection of Rainfall and Runoff in Rural Areas. London: IT Publication.

21. Qu Y., Su W., Zhang P P., et al.,2012. Effects of different water harvesting on soil water, 
growth and yield of the proso millet (Panicum miliaceum L.) in a semiarid region of northwest China. Journal of Agricultural Science. 4(9): 106-113.

22. Ramakrishna A., Tam H M., Wani S P., Long T D., 2006. Effect of mulch on soil temperature, moisture, weed infestation and yield of groundnut in northern Vietnam. Field Crops Research. 95, 115-125.

23. Ren, X.L. et al, 2008. Effect of a rainwater-harvesting furrow/ridge system on spring corn productivity under simulated rainfalls. Acta ecologica sinica. 28(3): 1006-1015.

24. Shao, H.B., Chu, L.Y., Wu, G., Zhang, J.H., Lu, Z.H., 2007. Where is the road to bio-water saving for the globe? Colloids Surf. BBiointerfaces 55 (2), 251-254.

25. Smith, D.R., Warnemuende, E.A., Huang, C., Heatman, G.C., 2007. How does the first year tilling a long-term no-tillage field impact soluble nutrient losses in runoff ? Soil and Tillage Research. 95, 11-18.

26. Song Q H. et al, 2002. Effect of various mulching durations with plastic film on soil microbial quantity and plant nutrients of spring wheat field in semi-arid loess plateau of China. Acta Ecologica Sinica. 22 (12), 2127-2132 (in Chinese with English abstract).

27. Tian Y., Derong S., Li F M., Li X L., 2003. Effect of rainwater harvesting with ridge and furrow on yield of potato in semiarid areas. Field Crops Research. 84, 385-391.

28. Truman, C.C., Shaw, J.N., Flanagan, D.C., Reeves, D.W., Ascough II, J.C., 2009. Conservation tillage to effectively reduce interrill erodibility of highly-weathered Ultisols. Journal of Soil and Water Conservation. 64 (4), 265-275.

29. Wang F X., Kang Y H., Liu S P., 2003. Plastic mulching effects on potato under drip irrigation and furrow irrigation. Chinese Journal of Eco-Agriculture. 11 (4), 99-102 (in Chinese with English abstract).

30. Wang X L, Li F M, Yu J., 2005. Increasing potato yields with additional water and increased soil temperature. Agricultural Water Management. 78: 181-194.

31. Wang Y J., Xie Z K., Malhi S S., Vera C L., Zhang Y B., Wang J N., 2009. Effects of rainfall harvesting and mulching technologies on water use efficiency and crop yield in the semi-arid Loess Plateau, China. Agricultural Water Management. 96, 374-382.

32. Wang, H.X. et al, 2001. Improving water use efficiency of irrigated crops in the North China Plain-measurements and modelling. Agric. Water Manage. 48, 151-167.

33. Wu, K., Tang, D.Y., Xie, X.Q., 2000. The issues and managements of water in the typical regions in the Huang-Huai-Hai Plain. Prog. Geogr. 19, 136-141.

34. Xiaolong, R., Zhikuan, J., Xiaoli, C., 2008. Rainfall concentration for increasing corn production under semiarid climate. Agric. Water Manage. 95, 1293-1302.

35. Xie, Z.K., Wang, Y.J., Li, F.M., 2005. Effect of plastic mulching on soil water use and spring wheat yield in arid region of northwest China. Agric. Water Manage. 75, 71-83.

36. Yang W. et al, 2015. Effects of ridge and furrow rainfall harvesting system combined with irrigation on improving water use efficiency of maize (Zea mays L.) in semi-humid area of China. Agricultural water management, 158, 1-9.

37. Zhang S L., Li P R., Yang X Y., et al., 2011. Effects of tillage and plastic mulch on soil water, growth and yield of spring-sown maize. Soil and tillage Res. 112: 92-97.

38. Zhang, J.Y., Sun, J.S., Duan, A.W., Wang, J.L., Shen, X.J., Liu, X.F., 2007. Effects of different planting patterns on water use and yield performance of winter wheat in the Huang-Huai-Hai plain of China. Agric. Water Manage. 92, 41-47. 